\title{
An Analysis of Students' Perception on Code Mixing Used in ELT: A Case Study at Dwijendra Primary \& Secondary School
}

\author{
I Putu Yoga Purandina \\ Program Studi Pendidikan Anak Usia DIni, Jurusan Dharma Acarya, Sekolah Tinggi Agama Hindu Negeri Mpu \\ Kuturan Singaraja \\ yogapurandina@stahnmpukuturan.ac.id
}

\section{Gede Sutrisna}

Program Studi Pendidikan Bahasa Inggris, Fakultas Keguruan dan Ilmu Pendidikan, Universitas Dwijendra gedesutrisna@undwi.ac.id

I Putu Yudi Sudarmawan

Program Studi Pendidikan Bahasa Inggris, Fakultas Keguruan dan Ilmu Pendidikan, Universitas Dwijendra sudarmawan@undwi.ac.id

\begin{abstract}
Abstrak
Campur kode sering terjadi dalam tuturan siswa dan guru di kelas Bahasa Inggris. Sehingga perlu dilakukan investigasi yang melibatkan persepsi siswa untuk mengetahui penggunaan campur kode dari sudut pandang siswa. Penelitian ini bertujuan untuk menganalisis persepsi siswa tentang penggunaan campur kode dalam ELT di SDN Dwijendra Denpasar. Penelitian ini merupakan penelitian kualitatif. Subjek penelitian ini adalah 99 siswa SD dan SMP Dwijendra yang terdiri dari 32 siswa kelas XI, 31 siswa kelas VIII dan 36 siswa kelas VI. Subyek tersebut ditentukan dengan purposive sampling. Pengumpulan data difasilitasi dengan menggunakan kuesioner tertutup. Kuesioner yang diadaptasi dari Khairunnisa (2016) adalah kuesioner tipe Likert yang terdiri dari 13 item. Hasilnya adalah siswa memiliki persepsi positif tentang penggunaan campur kode oleh guru mereka selama proses belajar mengajar bahasa Inggris. Mereka percaya bahwa cara guru mereka memadukan bahasa Indonesia dan bahasa Inggris di kelas bahasa Inggris mereka dapat memberi mereka paparan yang cukup saat mereka belajar bahasa Inggris. Selain itu, dapat meningkatkan pemahaman mereka dan membantu mereka mempelajari kata-kata bahasa Inggris baru.
\end{abstract}

Kata Kunci: Persepsi Siswa, Campur Kode, Pembelajaran Bahasa Inggris

\begin{abstract}
Code mixing often occurs in the utterance of students and teachers in EFL classes. So it is necessary to conduct an investigation that involves students' perceptions to find out the use of code-mixing from the student's perspective. This study aims to analyze students' perceptions of the use of code-mixing in ELT at Dwijendra Primary and Secondary School Denpasar. This research is qualitative. The subjects of this research were 99 students of Dwijendra primary and secondary school consisting of 32 eleventh grade students, 31 eighth grade students, and 36 sixth grade students. Those subjects were determined with purposive sampling. The data collection was facilitated by using a closed-ended questionnaire. The questionnaire, as adapted from Khairunnisa (2016), was a Likert-type questionnaire that consists of 13 items. The result is students had a positive perception of their teachers' use of code-mixing during the English teaching and learning process. They believed that the way their teachers mix Indonesian and English in their English class could provide them sufficient exposure while they learn English. In addition, it could promote their understanding and help them to learn new English words.
\end{abstract}

Keywords: Students' Perception, Code mixing, ELT 


\section{INTRODUCTION}

The term sociolinguistic can be generalized into two words; socio and linguistic. Socio relates to the society that interacts with each other and linguistic refers to the language that the citizen speaks (Verhoven, 2017; Sudarmawan et al, 2020). Sociolinguistic serves as a continuous process that will always be renewed as people interact with each other, especially among those in modern society where people are bilingual or multilingual. Paap, Schwitier and Paradis (2019) stated that bilingual or multilingual can be defined as two or more languages uttered by a person while communicating with interlocutors in a conversation. Being bilingual or multilingual will bring certain way of communication in society, such as code switching or code mixing.

Bilingualism and Multilingualism have become popular in the past few years which become parts of modern society living nowadays (Purandina et al., 2014). Multilingualism is mastering two languages or more than two languages such as the first and second language although the ability in mastering the two-second language of the second language is not as well as the first language (Herwig, 2001; Medvedkrajnovic, 2001). The evolution of bilingualism in the social environment makes code-switching common in social interaction, by definition codeswitching is a change made by a speaker from the mother language to a foreign language.

Code-switching can occur when a speaker communicates in a different language when one speaker of one language does a conversation with the other speaker in a different language (Richards \& Schmidt, 2013). Üstünel in 2016 had mentioned that code-switching broadly defines as the ability of bilingualism to alternate use between their two languages, moreover, they emphasized the codeswitching can be observed as social construct reflection and the cognitive mechanism of the user to control the use of both languages switching. Therefore, the use of code-switching could be either in informal or formal situations (Gumperz, 1977; Zakaria et al., 2005). Meanwhile, In the informal situation, people tend to switch the language in their daily conversation; such as the conversation at home, at the restaurant, or in public places while the use in the formal situation mostly at school interaction, government office, or other (Sudarmawan, 2018).

In the school interaction, the teachers mostly use code-switching in teaching the learning material (Sudarmawan et al., 2014). It is supported by (Üstünel, 2016) who stated that language contact occurs between the teaching-learning and the student's native language in classroom interaction. The use of full English in the class activity promotes confusion for the students (Huang et al., 2019). Because it's difficult for them to understand the topic that the teacher delivers, as a result, the students tend to be unmotivated in a learning activity (Sutrisna \& Juliari, 2019). Gardner-Chloros (2009) in Fitriyani (2013) stated that switching between two or more language needs the comprehension of both languages as a process in the speaker's brain and produce the alternation of the language. The use of more than two languages becomes the alternative medium of instruction in teaching the target language (Sutrisna \& Artini, 2020; Sutrisna, 2021). On the contrary, (Bullock \& Toribio, 2009) mentioned that commonly parents and professionals have a misconception about the code-switching that is lack of proficiency of the 
user or it is a sign of linguistic confusion, this assumed that code-switching contributes to obstacles in EFL teaching and learning processes such as the use of code-switching is a lacking ability sign of students in using the target language. Code-switching is the failure of the users in choosing the dictions and also unable to remember the vocabulary in a conversation (Heredia \& Altarriba, 2001). Moreover; some teaching strategies prohibit the use of native language in the learning activity in the classroom, the use of the first language is not allowed and the target language only could be used in the class activity.

Based on two view points about the codeswitching used, the researcher is interested in analyzing the use of code-switching uttered by the teacher in teaching activity. The analysis will be conducted on student perception toward codeswitching serves in the EFL classroom. (Bullock \& Toribio, 2009), (Jingxia, 2010), and (Ahmad \& Jusoff, 2009) found that the code-switching used is helpful in teaching-learning activities such as improving the comprehension of the grammar aspects, the word meaning, comparison between two languages, and reduce the students' stress. Code-switching is a strategy suit implemented in EFL, furthermore, it will help the teacher in using teaching strategy for classroom interaction and communication; convey clear and understandable instruction of teaching material to avoid confusion to the student of EFL class (Ismail et al., 2019; Samad \& Tidore, 2015).

As happened in Dwijendra primary and secondary school. In learning English (EFL). Teachers are accustomed to using English language learning (EFL) as a foreign language (TEFL) by applying the principle of bilingualism. It can even be called multilingualism because teachers usually use more than two languages. The languages used are English, Indonesian, and Balinese (Purandina \& Wedananta, 2021). English is used because in teaching English to students, they should use English. Indonesian is used because it uses the National Language and Balinese is used because the location of this English class is in Bali.

We know that in the TEFL class learning will not be able to be done using English alone. Mother tongue or local native language will not be ruled out (Miles, 2004; Zacharias, 2003). Thus, it is necessary to involve the First Language as a foundation and bridge to the understanding of concrete meaning. The first language will often be used even though the Kangding is used as an unintentional act. Likewise, sometimes teachers also do it on purpose.

Code mixing and code-switching are common in the classroom. However, code-mixing is more common. Likewise, the utterance produced by students usually occurs in code-mixing. They will find it difficult to lose their first language, so it is always included in their English utterance (Suhandoko, 2019). Indonesian and Balinese languages almost always appear in every utterance produced by students. This cannot be ruled out from various aspects, such as the mention of the original Indonesian term, or regionalism. Or there is an error in utterance which is still influenced by the first language.

As research conducted by Purnamasari et al., in 2016, where there was code-mixing that was intentionally used by SMAN Bali Mandara teachers in the 2014/2015 academic year. In detail, it was found that there were 14 sentences, classified as congruent lexicalization processes. The reasons 
for using code mixing were, 1) to make the intention of clarifying the speech content for interlocutor, 2) to be empathic about something, 3) there is no appropriate word which can be understood by the students, 4) to help the teacher to create relax situation, and 5) to quote somebody (Purnamasari et al., 2018).

Research conducted by Ningrum in 2019 at SMP Negeri 3 Busungbiu, Buleleng, found the results of using code-mixing by students in writing narrative texts. In detail, it is known that the purpose of using code-mixing is helping the readers to know that code-mixing is often found in students learning foreign languages, especially English. They don't know much vocabulary in English, so they use their first language to express what they want to communicate. This result of this research also is expected as feedback in improving the teaching process so students can improve their English knowledge without depending on the use of code mix (Ningrum, 2019).

Research by Ginting in 2019 on Analysis of Code-Switching and Code-Mixing in the Learning Process of Indonesia Subject at Grade 3 of SD Negeri 2 Jayagiri. The analysis shows that the occurrence of these phenomena was related to the habituation of the teacher and students in communication and the purpose to facilitate effective teaching and learning. The use of codeswitching and code-mixing has some implications on language development, teacher, and policy of using Indonesian as a medium of instruction (Ginting, 2019).

The use of code-switching in the EFL class is essential in Indonesia, especially in Bali. However, even so, further research is needed on how students perceive code-mixing that occurs in the EFL class.
So that in this study the researcher is interested in knowing more about students' perception of codemixing used in elt.

\section{RESEARCH METHODS}

This research was designed as qualitative research. The subjects of this research were 99 students of Dwijendra primary and secondary school consisting of 32 eleventh grade students, 31 eighth grade students, and 36 sixth grade students. Those subjects were determined with purposive sampling.

The data collection was facilitated by using a closed-ended questionnaire. The questionnaire, as adapted from Khairunnisa (2016), was a Likerttype questionnaire that consisted of 13 items. There was a response scale for each item that respondents used to indicate their level of agreement with each statement. The response scale ranged from one to four, and values for the scale were as follows: $4=$ Strongly Agree, 3 = Agree, 2 = Disagree, $1=$ Strongly Disagree. To execute a better analysis, the scales were reversed for the negative items. For seamless online sharing, the questionnaire was then formatted into Google Form.

For the sake of efficiency and accuracy, the collected data were then descriptively analyzed in terms of mean, range, and standard deviation with the assistance of Microsoft Excel.

At last, to determine respondents' perception, the mean score obtained from the result of the analysis would be carefully taken into the respondents' perception category as follows. 
Table 1 Respondents' Perception Category

\begin{tabular}{|c|c|}
\hline Range of the Data & Category \\
\hline $\bar{X} \geq 42$ & Highly Positive \\
\hline $34 \leq \bar{X}<42$ & Positive \\
\hline $29 \leq \bar{X}<34$ & Fair \\
\hline $23 \leq \bar{X}<29$ & Negative \\
\hline $\bar{X}<23$ & Highly Negative \\
\hline
\end{tabular}

\section{FINDINGS AND DISCUSSION}

The data on students' perception of codemixing used by English teachers in the English teaching and learning process was obtained through a questionnaire. The questionnaire was distributed on Tuesday, 11th May 2021 to 99 students of Dwijendra primary and secondary school as the respondents. The data obtained from the questionnaire was then analyzed thoroughly. The result of the analysis could be presented as follows.

The first question asked the students whether they agreed when their teachers mix Indonesian and English during the English teaching and learning process. The results pointed out that 29 students (29.3\%) were found to strongly agree, then $62(62.6 \%)$ students agreed when their teachers mix Indonesian and English during the English teaching and learning process. Only a few of them were noticed to disagree. Considering their responses, it was revealed that most of the students enjoyed it when their teachers used code-mixing (Indonesian - English) in English class.

The second up to the fifth question asked for the students' agreement on the teachers' frequency in mixing Indonesian and English during the English teaching and learning process. The results revealed that 63 students $(63.6 \%)$ were found to agree when their teachers always mix Indonesian and English during the English teaching and learning process. Then, 28 students $(28.3 \%)$ strongly agreed that their teachers frequently mix codes during English class. There was 1 student $(1.0 \%)$ found to strongly disagree when their teachers seldom use code-mixing in teaching English. Surprisingly, there were 66 students (66.7 $\%$ ) found to disagree if their teachers never mix codes during the English teaching and learning process. Therefore, it could be inferred that the majority of students were into the way their teachers teach English by mixing Indonesian and English in such high frequency.

For the sixth question, it was revealed that 38 students (38.4\%) were found to strongly agree; and 57 students $(57.6 \%)$ agreed that the use of Indonesian and English in the English teaching and learning process brings advantage to the students. Yet, there were only 4 students $(4.0 \%)$ found to disagree with the beneficial use of code-mixing in English class.

For the seventh question, it was revealed that 29 students $(29.3 \%)$ were found to strongly agree; and 61 students (61.6\%) agreed when their teachers mix Indonesian and English in defining or explaining new vocabulary. Meanwhile, the rest 9 students $(9.1 \%)$ were found to disagree with the way teachers mix codes in providing definitions or explanations on new vocabulary. Thus, it could be inferred that most of the students have been benefited from the use of code-mixing to learn new vocabulary.

For the eighth question, it was revealed that 33 students ( $33.3 \%$ ) were found to strongly agree; and 59 students (59.6\%) agreed when their 
teachers mix Indonesian and English in explaining lesson or course content. Meanwhile, the rest 7 students $(7.1 \%)$ were found to disagree with such a condition.

For the ninth question, it was revealed that 24 students $(24.2 \%)$ were found to strongly agree; and 60 students $(60.6 \%)$ agreed when their teachers mix Indonesian and English in giving instruction. Meanwhile, the rest 15 students $(15.2 \%)$ were noticed to exhibit disagreement.

For the tenth question, it was revealed that 32 students $(32.3 \%)$ were found to strongly agree; and 61 students $(61.6 \%)$ agreed that they could have a better understanding of the lesson when their teachers mix codes (Indonesian and English) in explaining lesson or course content. Meanwhile, the rest 6 students $(6.1 \%)$ were found to disagree that the use of code-mixing affects their understanding of the lesson.

The last three questions, questions 11 to 13 asked for students' responses whether they encountered any problems when their teachers mix Indonesian and English in explaining lesson or course content. The results revealed that only 30 out of 99 students $(30.3 \%)$ responded that they were experiencing problems in learning English when their teachers mix codes. It was further found that only 11 students (11.1\%) felt that they barely understood the lesson, and 15 other students (15.2 $\%)$ completely did not understand when their teachers mix Indonesian and English in their English class. Considering those results, it could be inferred that only a few students found it difficult to understand the lesson when their teachers mix codes.

Based on the entire result of the analysis, it was found that the students' mean score is 40 .
Regarding the perceptions' category, since the mean score $(\bar{X})<42$, it could be concluded that students' perception of the use of code-mixing in the English teaching and learning process was positive.

Mixing Indonesian and English during English class was perceived to help them to learn English. Most of them found it useful to understand the content of the lesson better and learn new vocabulary within more English exposure.

\section{IV.CONCLUSION}

The result of this research reveals that students of Dwijendra primary \& secondary school had a positive perception of their teachers' use of code-mixing during the English teaching and learning process. They believed that the way their teachers mix Indonesian and English in their English class could provide them sufficient exposure while they learn English. In addition, it could promote their understanding and help them to learn new English words.

\section{REFERENCES}

Ahmad, B. H., \& Jusoff, K. (2009). Teachers' Code-Switching in Classroom Instructions for Low English Proficient Learners. English Language Teaching, 2(2), p49. https://doi.org/10.5539/elt.v2n2p49

Bullock, B. E., \& Toribio, A. J. (2009). Cambridge Handbook of Linguistic Code-switching. 440.

Fitriyani, I. D. (2013). CODE-SWITCHING IS USED BY STUDENTS IN A SPEAKING CLASS ACTIVITY. 8.

Heredia, R. R., \& Altarriba, J. (2001). Bilingual Language Mixing: Why Do Bilinguals Code-Switch? Current Directions in Psychological Science, 10(5), 164-168. https://doi.org/10.1111/1467-8721.00140 
Jingxia, L. (2010). Teachers' Code-Switching to the L1 in EFL Classroom. The Open Applied Linguistics Journal, 3(1), 10-23. https://doi.org/10.2174/1874913501003010 010

Khairunnisa, K. (2016). Code Mixing Analysis in English Teaching-Learning Process at Senior High School 1 Takalar. Retrieved from http://repositori.uinalauddin.ac.id/8418/1/Khairunnisa.pdf

Richards, J. C., \& Schmidt, R. W. (2013). Longman Dictionary of Language Teaching and Applied Linguistics (0 ed.). Routledge. https://doi.org/10.4324/9781315833835

Üstünel, E. (2016). EFL Classroom CodeSwitching. Palgrave Macmillan UK. https://doi.org/10.1057/978-1-137-558442David Elkind \& Freddy Sweet. (2004). How to Do Character Education. http://www.goodcharacter.com/Article_4.ht $\underline{\mathrm{ml}}$.

Sudarmawan, IPY, DK Tantra, A Marheni (2014). The Effect Of Graphic Organizers And Text Types On The Students' reading Competency At Sman 8 Denpasar. Jurnal Pendidikan Bahasa Inggris Indonesia 2 (1) https://ejournal-

pasca.undiksha.ac.id/index.php/jpbi/article/v iew/2223

Sudarmawan, IPY (2018). President Jokowi's Campaign Speech On Mewujudkan Jakarta Baru; The Analysis of Illocutionary Act. Widya Accarya, 2018. http://ejournal.undwi.ac.id/index.php/widya accarya/article/view/618

Sudarmawan, I. P. Y., Swarniti, N. W., \& Susila, I. K. M. (2020). The Mistake Buster Technique for Sentence Construction Classroom Action Research at SMPN 1 Sukasada. LEJU (Language and Education Journal Undiksha), 3(1), 7-14. https://doi.org/10.23887/leju.v3i1.24588

Sutrisna, G., \& Juliari, I. G. A. I. T. (2019, December). Using 'problems' to promote students' writing skills in EFL. In Seminar Nasional Inovasi dalam Penelitian Sains, Teknologi dan Humaniora-InoBali (pp. 590596).
Sutrisna, G., \& Artini, L. P. (2020). Does ProblemBased Learning Affect Students' Speaking Skill and Attitude toward ELL?. RETORIKA: Jurnal Ilmu Bahasa, 6(2), 131138.

Sutrisna, G. (2021). Vocabulary Acquisition in EFL: A Literature Review of Innovative Vocabulary Teaching Strategies. Yavana Bhasha: Journal of English Language Education, 4(1), 8-17.

Ginting, C. R. (2019). Analysis of Code-Switching and Code-Mixing in the Learning Process of Indonesia Subject at Grade 3 of SD Negeri 2 Jayagiri. 254(22), 411-415. https://doi.org/10.2991/conaplin-18.2019.79

Gumperz, J. J. (1977). The Sociolinguistic Significance of Conversational CodeSwitching. RELC Journal, 8(2), 1-34. https://doi.org/10.1177/00336882770080020 1

Herwig, A. (2001). Chapter 7. Plurilingual Lexical Organisation: Evidence from Lexical Processing in L1-L2-L3-L4 Translation: (J. Cenoz, B. Hufeisen, \& U. Jessner (eds.); pp. 115-137). Multilingual Matters. https://doi.org/doi:10.21832/9781853595509008

Huang, B., Hew, K. F., \& Lo, C. K. (2019). Investigating the effects of gamificationenhanced flipped learning on undergraduate students' behavioral and cognitive engagement. Interactive Learning Environments, 27(8), 1106-1126. https://doi.org/10.1080/10494820.2018.1495 653

Ismail, Samad, I. S., \& Masnur. (2019). The impact of interactive reading using local folktales stories in supporting students, vocabulary achievement in Indonesian EFL learners. Majesty Journal, 1(2), 25-37.

Medved-krajnovic, M. (2001). First LanguageSecond Language : Friends or Enemies? 291-303.

Miles, R. (2004). EVALUATING THE USE OF L1 IN THE ENGLISH LANGUAGE CLASSROOM. March 2004. https://www.birmingham.ac.uk/Documents/c ollege- 
artslaw/cels/essays/matefltesldissertations/Mi lesdiss.pdf

Ningrum, A. C. K. (2019). An Analysis of Code Mixing in Students and Teacher Interaction in Narrative Texts in SMP Negeri 3 Busungbiu, Buleleng Islamic University of Malang Abstract. Language-Edu, 8(2), 1-8. https://www.google.com/url?sa=t\&rct=j\&q= $\&$ esrc $=$ s\&source $=$ web $\& c d=\& c a d=r j a \& u a c t=$ $8 \&$ ved=2ahUKEwib4e6K8sXtAhWSbn0KH YqdDTYQFjAAegQIAxAC\&url=http\%3A\% 2F\%2Friset.unisma.ac.id\%2Findex.php\%2FL ANG\%2Farticle\%2Fview\%2F2912\%2F0\&us $\mathrm{g}=\mathrm{AO}$ VVaw2OpJ5uFOqJaFHMcNXepKRd

Purandina, I. P. Y., Seken, I. K., \& Budasi, I. G. (2014). POLITENESS IN EFL CLASSROOM INTERACTIONS AND ITS IMPLICATIONS TOWARD EFL TEACHING-LEARNING IN SMP NEGERI 2 TABANAN IN THE ACADEMIC YEAR 2013/2014. In Jurnal Pendidikan Bahasa Inggris (Vol. 2, Issue 1). https://doi.org/10.23887/jpbi.v2i1.1386

Purandina, I. P. Y., \& Wedananta, K. A. (2021). Spirit of Balinese Local Heroes Transformed into Puppets Show on YouTube as ELT Media for Building Students' Character. Jurnal Pendidikan Dan Pengajaran, 54(1), 80. https://doi.org/10.23887/jpp.v54i1.33001

Purnamasari, N. M. G., Putra, I. N. A. J., \& Suwastini, N. K. A. (2018). A Descriptive Study on the Use of Code Mixing by the English Teacher at SMAN Bali Mandara in the Academic Year 2014/2015. Lingua Scientia, 23(2), 1. https://doi.org/10.23887/ls.v23i2.16070

Samad, F., \& Tidore, N. (2015). Strategi Pembelajaran Bahasa Inggris Yang Menyenangkan Untuk Anak Usia Dini. Cahaya PAUD, 2, 47-57.

Suhandoko, S. (2019). Codemixing in an Entertainment TV Show: How Which Is Functions in Indonesians' Repertoire. NOBEL: Journal of Literature and Language Teaching, 10(1), 32-51. https://doi.org/10.15642/nobel.2019.10.1.3251

Zacharias, N. (2003). A survey of tertiary teachers ' beliefs about English Language Teaching in
Indonesia ... Tesis, August.

Zakaria, M. H., Ida, R., \& Stephen, A. (2005). Code-Switching In Informal Interaction Among A Group Of 4 Year Tesl Students Of Utm. 